KESEHATAN

VOL. 1 NO. 01, DESEMBER 2021

DOI:

\title{
Pemberdayaan Masyarakat Melalui Program KEPALA (Kelompok Pengelola) Sampah
}

\author{
Elina Haqie, Icca Stella Amalia, Iding Budiman, Icka Irma, Regia Rohmania Putri, Rita Nuryati, Nita \\ Agustina Sari \\ STIKes Kuningan
}

Email: elinahaqie@gmail.com

\begin{abstract}
Abstrak
Pendahuluan: Di Indonesia, data Bank Dunia menyebutkan, produksi sampah padat secara nasional mencapai 151.921 ton per hari. Setiap penduduk Indonesia membuang sampah padat rata-rata $0,85 \mathrm{~kg}$ per hari. Hal ini masih kerap terjadi di Indonesia dikarenakan masih kurangnya kesadaran masyarakat tentang menjaga lingkungan. Tujuan: kegiatan intervensi ini adalah untuk mengubah perilaku masyarakat dalam pembuangan dan pengelolaan sampah. Metode: observasional menggunakan metode kuantitatif dengan menilai pengetahuan dan tindakan masyarakat mengenai pengelolaan sampah yang ada di RT/RW 06/02 Desa Cipaku. Instrumen yang digunakan adalah lembar angket berisi pre-test dan post-test. Hasil: Secara umum kondisi sanitasi di Desa Cipaku masih perlu peningkatan dan perbaikan. Perilaku penanganan sampah oleh masyarakat Desa Cipaku masih kurang baik. Oleh karena itu, kami merumuskan alternatif pemecahan masalah, dan alternatif yang terpilih adalah program KEPALA Sampah. Pelaksanaan kegiatan intervensi dilaksanakan dalam waktu 14 hari secara berturut turut. Kegiatan utama dalam program Kepala Sampah ini adalah pengangkutan sampah oleh petugas setiap $2 \mathrm{x} /$ minggu. Berdasarkan pengolahan data pre-test dan post-test menggunakan uji Wilcoxon diperoleh nilai probabilitas sebesar 0,000 atau lebih kecil dari 0,005 ( $p<0,05)$. Kesimpulan: ada pengaruh penyuluhan terhadap tingkat pengetahuan masyarakat Desa Cipaku.
\end{abstract}

Kata Kunci: Pemberdayaan, Masyarakat, Pengelolaan Sampah, Program KEPALA Sampah, Desa Cipaku

\section{PENDAHULUAN}

Penanganan sampah pemukiman memerlukan partisipasi aktif individu dan kelompok masyarakat selain peran pemerintah sebagai fasilitator. Ketidak pedulian masyarakat terhadap sampah akan berakibat terjadinya degradasi kualitas lingkungan yang akan mempengaruhi 
JURNAL PEMBERDAYAAN DAN PENDIDIKAN

KESEHATAN

VOL. 1 NO. 01, DESEMBER 2021

DOI:
Ciptaan disebarluaskan di bawah

Lisensi Creative Commons Atribusi-

NonKomersial-BerbagiSerupa 4.0

Internasional.

kualitas hidup masyarakat di sebuah wilayah. Degradasi kualitas lingkungan dipicu oleh perilaku masyarakat yang tidak ramah dengan lingkungan, seperti membuang sampah dibadan air (Tiara Dewi, Muhammad Amir Masruhim, 2016)

Di Indonesia, data Bank Dunia menyebutkan, produksi sampah padat secara nasional mencapai 151.921 ton per hari. Hal ini berarti, setiap penduduk Indonesia membuang sampah padat rata-rata $0,85 \mathrm{~kg}$ per hari. Data yang sama juga menyebutkan, dari total sampah yang dihasilkan secara nasional, hanya $80 \%$ yang berhasil dikumpulkan. Sisanya terbuang mencemari lingkungan. Berdasarkan data hasil Survei Dasar Kesehatan Masyarakat (SDKM) yang dilakukan pada saat PBL-I menunjukkan bahwa seluruh rumah tangga di RT/RW 06/02 Desa Cipaku Kecamatan Kadipaten Kabupaten Majalengka memiliki perilaku yang kurang baik dalam membuang sampah yaitu sebanyak 30 KK (100 \%). Kebanyakan dari masyarakat membuang sampah sembarangan ke Kebun yaitu sebanyak 30 KK (100 \%).

Sampah selalu menjadi masalah bagi pemerintah, bahkan diperkirakan sampah setiap harinya di Indonesia ini mencapai 200 ribu ton. Menteri Lingkungan Hidup dan Kehutanan (LHK), Siti Nurbaya, mengungkapkan jumlah timbulan sampah nasional yang ada saat ini masih sangat besar, yaitu mencapai sekitar 67,8 juta ton pada 2020. Jumlah ini diprediksi masih akan terus bertambah jika tidak ada upaya-upaya serius yang dilakukan (Sudoyono, 2021) Pemerintah menargetkan pengurangan sampah rumah tangga dan sampah sejenis sampah rumah tangga pada 2018 mencapai 15 persen. Hingga 2025, ditargetkan mencapai 30 persen (Malia, 2018) .

Upaya pengelolaan untuk mengatasi permasalahan sampah sudah dilakukan, namun belum tuntas. Peran serta masyarakat dibutuhkan dalam mengatasi permasalahan sampah. Pemerintah, masyarakat dan perubahan pola pikir masyarakat terhadap sampah merupakan komponen penting bagi pengelolaan sampah yang memadai (Rahman et al., 2020).

\section{MASALAH}

Secara umum kondisi sanitasi di Desa Cipaku masih perlu peningkatan dan perbaikan. Berdasarkan data yang diambil dari hasil survei laporan PBL-I yang dilaksanakan pada bulan Februari sampai bulan Maret 2021 di desa Cipaku, didapatkan hasil bahwa masyarakat desa Cipaku khususnya RT 06 RW 02 Dusun Cangkudu membuang sampah ke kebun sebanyak $100 \%$ dengan total 30 responden yang diwawancarai, sedangkan pada survei itupun seluruh masyarakat sudah memiliki tempat sampah masing-masing dengan jumlah tempat sampah rata- 
JURNAL PEMBERDAYAAN DAN PENDIDIKAN

KESEHATAN

VOL. 1 NO. 01, DESEMBER 2021

DOI:
Ciptaan disebarluaskan di bawah

Lisensi Creative Commons Atribusi-

NonKomersial-BerbagiSerupa 4.0

Internasional.

rata di setiap rumah adalah satu tempat sampah. Hal ini menggambarkan, perilaku penanganan sampah oleh masyarakat Desa Cipaku kurang baik. Oleh karena itu, kami melakukan perumusan alternatif solusi pemecahan masalah, Kemudian diperoleh hasil bahwa alternatif solusi pemecahan masalah sampah terpilih di Desa Cipaku adalah program KEPALA (Kelompok Pengelola) Sampah.

\section{METODE PELAKSANAAN}

Metode yang digunakan pada kegiatan ini adalah kuantitatif yaitu dengan menilai pengetahuan dan tindakan masyarakat mengenai pengelolaan sampah yang ada di RT/RW 06/02 Desa Cipaku. Instrumen yang digunakan adalah dengan mengisi lembar angket berisi pre-test dan post-test. Instrumen pengetahuan mencakup: Pengertian sampah, Pengertian pengelolaan sampah, Sumber-sumber sampah, Karakteristik berdasarkan jenis sampah, Cara penularan penyakit akibat buang sampah sembarangan, Jenis penyakit yang muncul akibat buang sampah sembarangan dan Dampak yang timbul akibat sampah.

Kegiatan dilakukan dengan cara pendekatan langsung seperti melakukan kegiatan pembersihan sampah dikebun dilakukan dengan cara gotong royong bersama warga setempat, mengelola sampah anorganik menggunakan metode ecobrick, melakukan penyuluhan mengenai sampah menggunakan metode door to door, menambah pengetahuan mengenai sampah secara tertulis dengan metode penempelan poster di tempat-tempat umum.

Berikut disajikan bagan kerangka penyelesaian masalah sebagai berikut :

\begin{tabular}{|c|c|c|}
\hline $\begin{array}{c}\text { INPUT } \\
\text { Masyarakat } \\
\text { RT/RW 06/02 } \\
\text { Desa Cipaku, } \\
\text { Kecamatan } \\
\text { Kadipaten, } \\
\text { Kabupaten } \\
\text { Majalengka }\end{array}$ & $\begin{array}{c}\text { PROSES } \\
\text { Pemberdayaan } \\
\text { Masyarakat } \\
\text { melalui Program } \\
\text { KEPALA } \\
\text { (Kelompok } \\
\text { Pengelola) Sampah } \\
\text { dengan metode } \\
\text { penyuluhan secara } \\
\text { door to door }\end{array}$ & $\begin{array}{c}\text { OUTPUT } \\
\text { Mengubah perilaku masyarakat } \\
\text { dalam pembuangan dan } \\
\text { pengelolaan sampah. Dengan } \\
\text { adanya kepala sampah diharapkan } \\
\text { masyarakat tidak membuang } \\
\text { sampah sembarangan, serta dapat } \\
\text { memberdayakan masyarakat agar } \\
\text { mampu berinovasi sehingga dapat } \\
\text { mengurangi masalah akibat } \\
\text { sampah. }\end{array}$ \\
\hline
\end{tabular}

Gambar 1 Skema Kerangka Pemecahan Masalah 
JURNAL PEMBERDAYAAN DAN PENDIDIKAN

KESEHATAN

VOL. 1 NO. 01, DESEMBER 2021

DOI:
Ciptaan disebarluaskan di bawah

Lisensi Creative Commons Atribusi-

NonKomersial-BerbagiSerupa 4.0

Internasional

\section{HASIL DAN PEMBAHASAN}

Kegiatan pemberdayaan masyarakat melalui program KEPALA Sampah ini dilakukan dengan pendidikan masyarakat berupa penyuluhan pada masyarakat setempat tentang pengelolaan sampah. Pada kegiatan ini masyarakat diajak untuk berpatisipasi dalam program KEPALA Sampah. Kegiatan ini dilaksanakan untuk mengubah perilaku masyarakat dalam pembuangan dan pengelolaan sampah. Dengan adanya kepala sampah diharapkan masyarakat tidak membuang sampah sembarangan lagi, serta dapat memberdayakan masyarakat agar mampu berinovasi sehingga dapat mengurangi masalah akibat sampah. Hasil kegiatan penyuluhan kepada masyarakat menunjukkan terdapat peningkatan pengetahuan tentang pengelolaan sampah. Berikut disajikan tabel pengukuran pengetahuan:

Tabel 1. Distribusi Frekuensi

\begin{tabular}{lcccc}
\hline & \multicolumn{2}{c}{ Sebelum Penyuluhan } & \multicolumn{2}{c}{ Sesudah Penyuluhan } \\
\hline \multicolumn{1}{c}{ Pengetahuan } & Frekuensi & Persentase (\%) & Frekuensi & Persentase (\%) \\
\hline Kurang & 15 & 50 & 0 & 0 \\
Cukup & 11 & 36,7 & 5 & 16,7 \\
Baik & 4 & 13,3 & 25 & 83,3 \\
\hline Total & 30 & 100 & $\mathbf{3 0}$ & $\mathbf{1 0 0}$ \\
\hline
\end{tabular}

Berdasarkan hasil dari tabel 1 dapat diketahui bahwa tingkat pengetahuan masyarakat Desa Cipaku Sebelum diadakannya penyuluhan sebagian besar memiliki pengetahuan yang kurang yaitu sebanyak 15 orang (50\%), sedangkan yang memiliki pengetahuan cukup sebanyak 11 orang $(36,7 \%)$ sebelum dilakukannya penyuluhan sedangkan setelah diadakannya penyuluhan ada 5 orang $(16,7 \%)$ yang berpengetahuan cukup, dan yang memiliki pengetahuan baik sebanyak 4 orang $(13,3 \%)$ sebelum dilakukannya penyuluhan dan sesudah dilakukannya penyuluhan sebanyak 25 orang $(83,3 \%)$, dapat disimpulkan adanya perubahan pengetahuan mengenai pengelolaan sampah dari sebelum dan sesudah penyuluhan dilakukan.

Tabel 2. Uji Normalitas

\begin{tabular}{lllllll}
\hline & \multicolumn{3}{c}{ Kolmogorov-Smirnov } & \multicolumn{3}{c}{ Shapiro-Wilk } \\
\hline & Statistic & Df & Sig. & Statistic & Df & Sig. \\
\hline Pre Test & 0,311 & 30 & 0,000 & 0,760 & 30 & 0,000 \\
Post-test & 0,503 & 30 & 0,000 & 0,452 & 30 & 0,000 \\
\hline
\end{tabular}


JURNAL PEMBERDAYAAN DAN PENDIDIKAN

KESEHATAN

VOL. 1 NO. 01, DESEMBER 2021

DOI:
Ciptaan disebarluaskan di bawah

Lisensi Creative Commons Atribusi-

NonKomersial-BerbagiSerupa 4.0

Berdasarkan tabel 2 terdapat tabel hasil dari uji normalitas (Kolmogorov Smirnov dan Shapiro Wilk) dari setiap data (pre-testdan post-test). Nilai pada kolom (Kolmogorov Smirnov) sig. Menunjukan untuk pre-test 0,000 dan post-test 0,000. Berdasarkan aturan jika nilai sig lebih besar dari 0,05 maka data tersebut dikatakan normal, maka metode yang tepat untuk digunakan yaitu uji T. Sedangkan jika nilai sig kurang dari 0,05 maka data tersebut tidak normal dan metode yang paling tepat yaitu menggunakan uji wilcoxon. Pada data di atas menunjukan nilai sig kurang dari $0,05(0,000<0,005$ dan $0,000<0,005)$, maka data di atas tidak normal dan metode yang tepat untuk digunakan yaitu uji wilcoxon.

Tabel 3. Perbandingan Hasil Nilai Pre-test dan Post-test pada Responden Penyuluhan Pengelolaan Sampah

\begin{tabular}{rccc}
\hline Pengetahuan & Frekuensi & Mean Rank & P value \\
\hline Post-test $<$ Pre-test & 0 & 0,00 & \\
Post-test $>$ Pre test & 26 & 13,50 & 0,000 \\
Post-test $=$ Pre test & 4 & & \\
\hline Total & $\mathbf{3 0}$ &
\end{tabular}

Berdasarkan tabel 3 dapat diketahui bahwa sebagian besar peserta memiliki nilai posttest lebih besar dibandingkan dengan nilai pre-test yaitu sebanyak 26 orang. Hal ini menunjukkan bahwa dengan diadakannya penyuluhan dapat meningkatkan pengetahuan responden. Nilai probabilitas uji Wilcoxon berdasarkan tabel tersebut adalah 0,000 atau lebih kecil dari 0,005 $(p<0,05)$, maka dapat disimpulkan bahwa ada pengaruh penyuluhan terhadap tingkat pengetahuan masyarakat Desa Cipaku.

Pemberdayaan masyarakat desa didefinisikan sebagai upaya mengembangkan kemandirian dan kesejahteraan masyarakat dengan meningkatkan pengetahuan, sikap, keterampilan, perilaku, kemampuan, kesadaran, serta memanfaatkan sumber daya melalui penetapan kebijakan, program, kegiatan, dan pendampingan yang sesuai dengan esensi masalah dan prioritas kebutuhan masyarakat desa (Mujianto, 2019)

Dalam upaya agar masyarakat berdaya maka memerlukan intervensi. Ada beberapa tahapan intervensi yang direncanakan agar tercapai keberhasilan pemberdayaan tersebut. Tahapan yang dilakukan lebih dekat sebagai upaya pengembangan masyarakat. Pengembangan masyarakat yang dilakukan diharapkan berujung pada terrealisasinya proses pemberdayaan masyarakat (Mujianto, 2019). Pengelolaan sampah adalah kegiatan yang sistematis, menyeluruh, dan berkesinambungan yang meliputi pengurangan dan penanganan sampah 
JURNAL PEMBERDAYAAN DAN PENDIDIKAN

KESEHATAN

VOL. 1 NO. 01, DESEMBER 2021

DOI:
Ciptaan disebarluaskan di bawah

Lisensi Creative Commons Atribusi-

NonKomersial-BerbagiSerupa 4.0

Internasional.

(Undang-Undang Republik Indonesia Nomor 18 Tahun 2008 Tentang Pengelolaan Sampah, 2008).

Secara umum kondisi sanitasi di Desa Cipaku masih perlu peningkatan dan perbaikan. Berdasarkan data yang diambil dari survey hasil laporan PBL-I yang dilaksanakan pada bulan Februari sampai bulan Maret 2021 di desa Cipaku, didapatkan hasil bahwa masyarakat desa Cipaku khususnya RT 06 RW 02 Dusun Cangkudu membuang sampah ke kebun sebanyak $100 \%$ dengan total 30 responden yang diwawancarai, sedangkan pada survei itupun seluruh masyarakat sudah memiliki tempat sampah masing-masing dengan jumlah tempat sampah ratarata di setiap rumah adalah satu tempat sampah. Hal ini menggambarkan, perilaku penanganan sampah oleh masyarakat Desa Cipaku kurang baik.

Kurangnya kesadaran tersebut juga dikarenakan kurangnya edukasi tentang sampah. Karena banyak yang belum mengetahui apa itu sampah, apa itu pengelolaan sampah, apa penyebab sampah lalu apa akibatnya, jenis-jenis sampah, dan lain-lain (Fatima, 2020)). Oleh karena itu, kami melakukan perumusan alternatif solusi pemecahan masalah, Kemudian diperoleh hasil bahwa alternatif solusi pemecahan masalah sampah terpilih di Desa Cipaku adalah program KEPALA (Kelompok Pengelola) Sampah. Struktur organisasi dari KEPALA Sampah sendiri yaitu Bapak Suharya selaku Dewan Penyantun, Bapak Ust. Yanto selaku Ketua pengelola sampah, Bapak Indra Komara selaku Supir mobil bak sampah dan Bapak Kadi selaku Pengangkut sampah. Adapun kegiatan dari program KEPALA Sampah yaitu:

1. Penyuluhan Secara Door to door

Penyuluhan tentang sampah dilakukan kepada masyarakat Desa Cipaku RT 06 secara door to door, Masyarakat yang terlibat dalam penyuluhan door to door sebanyak 30 responden. Tujuan dari kegiatan ini adalah untuk meningkatkan pengetahuan masyarakat tentang sampah dan pengelolaannya. Media yang digunakan adalah poster. Kegiatan ini dilaksanakan pada tanggal 30 Agustus 2021. Salah satu bentuk komunikasi yang dapat dilakukan ialah dengan sosialisasi (Wahyudin, 2017). Edukasi merupakan proses belajar dari tidak tahu menjadi tahu. Dalam kaitannya dengan edukasi pengelolaan sampah bagi masyarakat, maka diharapkan masyarakat mengetahui tentang pengelolaan sampah sehingga pengetahuannya dapat mempengaruhi individu, kelompok atau masyarakat di lingkungannya (Sekarningrum et al., 2020).

2. Kerja Bakti dan Pemasangan Banner 
JURNAL PEMBERDAYAAN DAN PENDIDIKAN

KESEHATAN

VOL. 1 NO. 01, DESEMBER 2021

DOI:
Ciptaan disebarluaskan di bawah

Lisensi Creative Commons Atribusi-

NonKomersial-BerbagiSerupa 4.0

Mengadakan kerja bakti membersihkan lingkungan dan penempelan banner himbauan tentang larangan membuang sampah. Tujuannya adalah agar lingkungan tersebut bersih dan sehat serta masyarakat tidak membuang sampah sembarangan ke kebun. Kegiatan ini dilaksanan pada tanggal 4 September 2021. Kerja bakti ini dihadiri oleh perangkat desa, pengelola sampah juga melibatkan peran serta masyarakat setempat. Kerja bakti dihadiri minimal 30 orang peserta dan dapat terciptanya perubahan perilaku dalam penanganan sampah. Permasalahan kebersihan lingkungan selalu berkaitan dengan kesehatan masyarakat (Mea, 2020). Program promosi kesehatan melalui banner membuang sampah pada tempatnya penting peranannya dalam penyampaian pesan dan penjagaan kualitas kebersihan dan kesehatan lingkungan (Nursamsam et al., n.d.)

\section{Pengangkutan Sampah oleh Petugas}

Penangkutan sampah oleh petugas merupakan kegiatan utama dalam program Kepala Sampah. Pengangkutan sampah dilakukan dari rumah-rumah oleh petugas setiap $2 \mathrm{x} / \mathrm{minggu}$ untuk dikumpulkan dipinggir jalan yang kemudian akan diangkut kembali menggunakan mobil sampah dan dibuang ke Tempat Pembuangan Akhir (TPA). Kepala sampah ini akan dibayar oleh masyarakat sesuai kesepakatan untuk membayar iuran sampah. Kegiatan ini dilakukan rutin setiap hari rabu dan sabtu, dengan iuran sebesar Rp. 2500,- /sekali angkut.

\section{Pembuatan Ecobrick}

Ecobrick merupakan salah satu cara mendaur ulang sampah-sampah yang membutuhkan waktu sangat lama untuk dapat terurai sebagai usaha untuk menjaga kelestarian, kenyamanan, serta keselamatan lingkungan (Istirokhatun \& Nugraha, 2019). Pembuatan ecobrick merupakan salah satu upaya daur ulang (recycle) untuk mengurangi sampah plastik (Palupi et al., 2020). Hal ini dikarenakan masih banyaknya jumlah sampah anorganik yang belum terkelola dengan baik. Pelatihan pembuatan ecobrick ini juga dilakukan bersama anakanak RT 06 usia 11 - 12 tahun. Kegiatan ini dilaksanakan pada tanggal 9 - 10 September 2021.

\section{Penempelan Poster Edukasi}

Melakukan penempelan poster edukasi sampah di tempat-tempat umum di Desa Cipaku. Kegiatan penempelan poster ini dilaksanakan pada tanggal 13 September 2021. Program penempelan poster pembiasaan membuang sampah pada tempatnya merupakan upaya untuk menciptakan, mengedukasi, menghimbau dan memberikan informasi terkait pentingnya 
JURNAL PEMBERDAYAAN DAN PENDIDIKAN

KESEHATAN

VOL. 1 NO. 01, DESEMBER 2021

DOI:
Ciptaan disebarluaskan di bawah

Lisensi Creative Commons Atribusi-

NonKomersial-BerbagiSerupa 4.0

melakukan kebiasaan hidup sehat diantaranya dengan membiasakan membuang sampah pada tempatnya sehingga terciptanya masyarakat yang sehat (Wahyudin, 2017).

Berdasarkan hasil survey yang dilakukan terhadap 30 responden di RT/RW 06/02 Desa Cipaku menunjukkan bahwa terdapat peningkatan pengetahuan. Peningkatan pengetahuan dilakukan melalui penyuluhan. Mengingat situasi pandemi, penyuluhan dilakukan secara door to door. Walaupun begitu pelaksanaan penyuluhan berjalan dengan lancar.

Pengetahuan merupakan domain yang sangat penting untuk terbentuknya tindakan seseorang, pengelolaan sampah berhubungan erat dengan intelektual seseorang. Informasi merupakan faktor yang mempengaruhi pengetahuan seseorang. Semakin banyak seseorang memperoleh informasi tentang pengolahan sampah yang baik maka pengetahuannya akan semakin baik dan akan memiliki perilaku yang baik pula (Harun, 2017).

Tahap selanjutnya pada kegiatan ini adalah monitoring dan evaluasi. Monitoring dilaksanakan, mulai dari tahap persiapan program, sampai pada tahap akhir pelaksanaan kegiatan intervensi. Pelaksanaan intervensi dilakukan sesuai dengan kesepakatan yang telah ditetapkan, Pada saat evaluasi menunjukkan bahwa pelaksanaan interpensi berjalan cukup lancar, masyarakat mau diajak berpartisipasi dalam program KEPALA Sampah.

\section{KESIMPULAN DAN SARAN}

Secara umum kondisi sanitasi di Desa Cipaku masih perlu peningkatan dan perbaikan. Perilaku penanganan sampah oleh masyarakat Desa Cipaku masih kurang baik. Oleh karena itu, kami melakukan perumusan alternatif solusi pemecahan masalah, Kemudian diperoleh hasil bahwa alternatif solusi pemecahan masalah sampah terpilih di Desa Cipaku adalah program Kepala (Kelompok Pengelola) Sampah. Kegiatan pemberdayaan masyarakat dilaksanakan menggunakan metode kuantitatif dengan menilai pengetahuan masyarakat mengenai pengelolaan sampah yang ada di RT/RW 06/02 Desa Cipaku. Instrumen yang digunakan adalah dengan mengisi lembar angket berisi pre-testdan post-test. Berdasarkan pengolahan data pretest dan post-test menggunakan uji Wilcoxon diperoleh nilai probabilitas sebesar 0,000 atau lebih kecil dari 0,005 $(p<0,05)$, maka dapat disimpulkan bahwa ada pengaruh penyuluhan terhadap tingkat pengetahuan masyarakat Desa Cipaku. Pelaksanaan intervensi dilakukan sesuai dengan kesepakatan yang telah ditetapkan, dan hasil evaluasi menunjukkan bahwa pelaksanaan interpensi berjalan lancar, masyarakat mau diajak berpartisipasi dalam program KEPALA Sampah. 
JURNAL PEMBERDAYAAN DAN PENDIDIKAN

KESEHATAN

VOL. 1 NO. 01, DESEMBER 2021

DOI:
Ciptaan disebarluaskan di bawah

Lisensi Creative Commons Atribusi-

NonKomersial-BerbagiSerupa 4.0

\section{UCAPAN TERIMA KASIH}

Pelaksanaan kegiatan intervensi di Desa Cipaku Kecamatan Kadipaten Kabupaten Majalengka ini tidak terlepas dari kontribusi semua pihak yang telah membantu dalam terlaksananya sebuah kegiatan. Tim PBL-II memberikan penghargaan setinggi-tingginya kepada Kepala Desa, Pengurus RT/RW, Tim Penggerak PKK, seluruh Kader serta seluruh masyarakat yang terlibat. Tak lupa juga kami ucapkan terimakasih kepada para tokoh masyarakat, tokoh agama yang telah memberikan izin dan meminjamkan tempat untuk berjalannya semua kegiatan ini.

\section{DAFTAR PUSTAKA}

Fatima, A. (2020). Pentingnya Edukasi Tentang Pengelolaan Sampah Bagi Kehidupan. Jakartamedia.Co.Id. https://jakartamedia.co.id/pentingnya-edukasi-tentang-pengelolaansampah-bagi-kehidupan

Harun, H. (2017). Gambaran Pengetahuan dan Perilaku Masyarakat Dalam Proses Pemilahan Sampah Rumah Tangga Di Desa Hegarmanah. Jurnal Aplikasi Ipteks Untuk Masyarakat, 6(2), 86-88. http://journal.unpad.ac.id/dharmakarya/article/view/14789/7890

Istirokhatun, T., \& Nugraha, W. D. (2019). Pelatihan Pembuatan Ecobricks sebagai Pengelolaan Sampah Plastik di Rt 01 Rw 05, Kelurahan Kramas, Kecamatan Tembalang, Semarang. Jurnal Pasopati "Pengabdian Masyarakat Dan Inovasi Pengembangan Teknologi,” 1(2), 85-90. https://ejournal2.undip.ac.id/index.php/pasopati/article/view/5549\%0Ahttps://ejournal2.u ndip.ac.id/index.php/pasopati/article/download/5549/3111

Malia, I. (2018). Volume Sampah 2018 Diprediksi Mencapai 66,5 Juta Ton! https://www.idntimes.com/news/indonesia/indianamalia/volume-sampah-2018diprediksi-mencapai-665-juta-ton-1/3

Mea, M. H. C. D. (2020). Kampanye Kebersihan Lingkungan Melalui Program Kerja Bakti Mahasiswa Program Studi Manajemen Di Kelurahan Potulando, Kecamatan Ende Tengah, Kabupaten Ende. Mitra Mahajana: Jurnal Pengabdian Masyarakat, 1(1), 54-58. https://doi.org/10.37478/mahajana.v1i1.719

Mujianto, A. P. (2019). Pemberdayaan Masyarakat Desa. In Pemberdayaan Masyarakat: Vol. $I$ (Issue 2).

Nursamsam, Y., Rachmat, M., Thaha, R. M., Kesehatan, P., Ilmu, D., Fakultas, P., \& Masyarakat, K. (n.d.). Pemanfaatan Poster "Membuang Sampah Pada Tempatnya" Sebagai Media Promosi Kesehatan Di Puskesmas Batua Utilization of Poster "Disposing Waste on His Place" as a Health Promotion Media in Puskesmas Batua. Digilib.Unhas.Ac.Id. 
JURNAL PEMBERDAYAAN DAN PENDIDIKAN

KESEHATAN

VOL. 1 No. 01, DESEMBER 2021

DOI:
Ciptaan disebarluaskan di bawah

Lisensi Creative Commons Atribusi-

NonKomersial-BerbagiSerupa 4.0

Internasional.

Palupi, W., Wahyuningsih, S., Widiyastuti, E., Nurjanah, N. E., \& Pudyaningtyas, A. R. (2020). Pemanfaatan Ecobricks Sebagai Media Pembelajaran Untuk Anak Usia Dini. DEDIKASI: Community Service Reports, 2(1), 28-34. https://doi.org/10.20961/dedikasi.v2i1.37624

Rahman, R., Sididi, M., \& Yusriani, Y. (2020). Pengaruh Pengetahuan Dan Sikap Terhadap Partisipasi Masyarakat Dalam Pengelolaan Sampah Di Kampung Nelayan Untia. Jurnal Surya Muda, 2(2), 119-131. https://doi.org/10.38102/jsm.v2i2.70

Undang-Undang Republik Indonesia Nomor 18 Tahun 2008 Tentang Pengelolaan Sampah, (2008). https://pelayanan.jakarta.go.id/download/regulasi/undang-undang-nomor-18tahun-2008-tentang-pengelolaan-sampah.pdf

Sekarningrum, B., Sugandi, Y. S., \& Yunita, D. (2020). Sosialisasi dan Edukasi Kangpisman (Kurangi, Pisahkan dan Manfaatkan Sampah). Kumawula: Jurnal Pengabdian Kepada Masyarakat, 3(1), 73. https://doi.org/10.24198/kumawula.v3i1.25244

Sudoyono, W. (2021). Timbulan Sampah Nasional Capai 67,8 Juta Ton pada 2020. https://infopublik.id/kategori/nasional-sosial-budaya/512550/timbulan-sampah-nasionalcapai-67-8-juta-ton-pada-2020

Tiara Dewi, Muhammad Amir Masruhim, R. S. (2016). Laboratorium Penelitian Dan Pengembangan FARMAKA TROPIS Fakultas Farmasi Universitas Mualawarman, Samarinda, Kalimantan Timur, 2(April), 5-24.

Wahyudin, U. (2017). Strategi Komunikasi Lingkungan Dalam Membangun Kepedulian Masyarakat Terhadap Lingkungan. Jurnal Common, 1(2), 136-144. https://doi.org/10.34010/common.v1i2.576 